\title{
UJI KUAT LENTUR PROFIL BAJA RINGAN GALVALUM TIPE C YANG DI GROUTING DENGAN VARIASI MORTAR
}

\author{
Fadhila Firdausa ${ }^{*}$, Sri Rezki Artini ${ }^{2}$, Ahmad Syapawi $^{3}$ dan Puryanto ${ }^{4}$ \\ ${ }^{1}$ Dosen, Jurusan Teknik Sipil, Politeknik Negeri Sriwijaya \\ 2Dosen, Jurusan Teknik Sipil, Politeknik Negeri Sriwijaya \\ ${ }^{3}$ Dosen, Jurusan Teknik Sipil, Politeknik Negeri Sriwijaya \\ ${ }^{4}$ Dosen, Jurusan Teknik Sipil, Politeknik Negeri Sriwijaya \\ *Korespondensi: fadhilafirdausa@polsri.ac.id
}

\begin{abstract}
Cold form steel is one type of material that is currently experiencing very rapid development. The advantages of the using cold form steel are so many, one of which is the light weight and high quality steel. This is an added value for cold form steel. But one of the weakness in cold form steel profile is the buckling effect. So that additional fillers are needed so that cold form steel has resistance with buckling effect. Mortar is a filler that is often used in construction. Therefore this research will be discuss the analysis of grouting mortar to prevent buckling effect in the cold form steel profile. And then the grouting mortar that will be used uses a variation of cement to sand as big as 1:1, 1:2, 1:3 and 1:4. From the results of the compressive strength of the mortar obtained compressive strength of 1: 1 has the greatest compressive strength of $30 \mathrm{Mpa}$. And then for the flexural test, the steel beam with mortar variation 1: 1 has the greatest resistance of 9558 Newton, with the smallest deflection value of $8 \mathrm{~mm}$ and the greatest stress of $19.47 \mathrm{Mpa}$, when compared to steel beams with variations of $1: 2,1: 3,1: 4$ and steel beams without fillers.
\end{abstract}

Keywords : Grouting, Mortar, Buckling, Cold Form Steel

\section{PENDAHULUAN}

Baja ringan merupakan salah satu jenis material yang saat ini mengalami perkembangan yang sangat pesat. Keuntungan dari penggunaan baja ringan sangat banyak salah satunya yaitu beratnya yang ringan serta mutu baja yang tinggi. Hal ini menjadi nilai tambah bagi material baja ringan. Namun salah satu kekurangan pada profil baja ringan adalah lemah terhadap gaya lentur yang mengakibatkan tekuk yang mengakibatkan ketidakstabilan benda uji [1]. Sehingga diperlukan bahan pengisi tambahan agar baja ringan memiliki tahanan terhadap tekuk. Tegangan tekuk dapat disebut juga sebagai suatu proses di mana suatu struktur tidak mampu mempertahankan bentuk sesuai yang diharapkan. Galvalum merupakan bahan pembuat baja ringan. Galvalum sendiri terdiri dari campuran dari galvanis dan alumunium. Salah satu kelebihan dari galvalum adalah memiliki tahanan terhadap suhu sehingga tahan terhadap cuaca dan korosi.

Grouting merupakan proses dimana material semen, pasir, dan air diinjeksikan kedalam suatu ruang atau benda yang selanjutnya material yang telah diinjeksikan tersebut akan menyatu dengan bahan dari benda atau ruang tersebut. Mortar adalah campuran dari bahan atau material semen, pasir, dan air [2]. Mortar merupakan salah satu bahan pengisi yang sering digunakan dalam pembangunan konstruksi karena kemampuan tahanan mortar terhadap uji tekan. Berdasarkan latar belakang masalah diatas maka identifikasi masalah yang diangkat pada penelitian ini adalah untuk mendapatkan hasil dari kuat lentur yang maksimal dan mengurangi efek buckling/tekuk pada baja ringan galvalum 
dengan mengkombinasikan material baja ringan sebagai balok dan material variasi mortar sebagai bahan pengisi/grouting balok. Variasi mortar yang akan digunakan adalah perbandingan semen terhadap pasir sebesar 1:1, $1: 2,1: 3$ dan $1: 4$.

\section{TINJAUAN PUSTAKA}

2.1. Investigasi Eksperimental Perilaku Profil Baja Ringan Berpenampang Persegi Akibat Interaksi Beban Tekan Memusat dan Momen Lentur (Andi, dkk., 2013)

Penelitian ini [3] merupakan bagian dari program penelitian yang difokuskan pada pengembangan metode analisa kekuatan profil baja berdinding tipis berbentuk pipa kotak (Square Hollow Section/SHS) akibat interaksi beban tekan memusat dan momen lentur yang didasarkan pada pendekatan teori mekanisme plastis dan elastis (plastic mechanisms and elastic theories/cut-off strength) dimana tingkat akurasinya akan diverifikasi menggunakan hasil pendekatan experimental. Pada tahap pertama penelitian ini, analisa kekuatan SHS didasarkan pada desain standar yang ada yaitu British Standard (BS 5950 Part 5 1987) yang menggunakan metode langsung (direct method) dan metode dua kanal (double channels method). Pada metode eksperimental dilakukan pengujian awal yaitu pengujian material dasar dari SHS dan pengujian utama yaitu pengujian kekuatan profil baja berdinding tipis berbentuk pipa kotak akibat interaksi beban tekan memusat dan momen lentur. Data hasil uji material dasar digunakan sebagai data masukan pada analisis kekuatan profil baja berdinding tipis berbentuk pipa kotak menggunakan British Standard, sedangkan hasil uji kekuatan profil baja berdinding tipis berbentuk pipa kotak dijadikan sebagai acuan dari metode analisis kekuatan yang digunakan. Hasil analisa kekuatan SHS menunjukkan bahwa hasil analisa kekuatan dengan metode double channels memberikan hasil yang mendekati hasil experimental (perbedaan sekitar 2\% sampai 7\%) dibandingkan dengan metode lansung dan hal ini masih dalam batas-batas yang dapat diterima (acceptable limits) 20\%. Hasil pada tahap awal berupa hasil eksperimental dan hasil analisis kekuatan menggunakan standard desain cukup akurat dan akan digunakan sebagai pembanding dengan hasil dari metode analisa kekuatan yang dikembangkan pada tahap penelitian selanjutnya.

\subsection{Pengaruh Bentuk Badan Profil Baja Ringan Terhadap Kuat Tekan (Kezia Ruus, dkk., 2017) \\ Penelitian ini [4] membahas mengenai} baja ringan (cold formed steel) yang dipakai sebagai material struktur memberikan gagasan untuk melakukan inovasi yaitu, penggunaan material baja ringan pada struktur utama bangunan. Akibat dari penggunaan pelat yang tipis ini, pengaruh tekuk lokal pada badan dan flens penampang akan menjadi lebih signifikan dibanding baja biasa. Namun karena penggunaan pelat yang sangat tipis dan metode pembentukan dengan penggilingan dingin, maka penampang dapat digiling dalam berbagai bentuk yang lebih optimal. Untuk menaikkan kuat tekan penampang, kecenderungan untuk mengalami tekuk dapat dikurangi salah satunya dengan memodifikasi bentuk geometri penampang dengan menggunakan pengaku memanjang, atau biasa disebut pengaku tengah (intermediate stiffner).

Penelitian dilakukan terhadap profil kanal $\mathrm{C}$ dengan tiga bentuk modifikasi bentuk badan profil dimana mutu baja ringan mengikuti standar Australia (AS1397) yaitu G550 yang diaplikasikan pada seluruh profil yang akan dianalisis. Selanjutnya dilakukan pemodelan finite element dengan program Ansys Mechanical APDL. Analisis linear buckling (eigen buckling) digunakan untuk memperoleh besarnya beban kritis tekuk profil dan mode keruntuhan struktur. Setelah diperoleh besar beban kritis tekuk, maka hasil tersebut dibandingkan antara profil kanal $\mathrm{C}$ tanpa modifikasi badan profil $(\mathrm{C} 1)$ dengan profil kanal $\mathrm{C}$ yang dimodifikasi bentuk badan profilnya $(\mathrm{C} 2, \mathrm{C} 3$ dan $\mathrm{C} 4)$.

Dari analisis eigen buckling dengan finite element model diketahui bahwa dengan memodifikasi bentuk badan profil dapat mereduksi tekuk lokal yang terjadi pada badan profil sehingga dapat meningkatkan kemampuan tekan. Persentase peningkatan beban kritis yang terjadi pada short column sebesar 1.46\%-2.16\%, untuk intermediate column sebesar $0.08 \%-1 \%$ dan untuk long column sebesar $0.1 \%-0.12 \%$. Peningkatan beban kritis terbesar terjadi pada profil C3 untuk semua angka rasio kelangsingan yang dianalisis. 
2.3. Analisis Kuat Lentur Baja Ringan Dengan Variasi Bentuk Sayap dan Badan Penampang (Gabriela, dkk., 2019)

Dalam penelitian ini [5] meneliti mengenai baja ringan (Cold Formed Steel) digunakan sebagai struktur bangunan. Secara signifikan mulai tampak beberapa inovasi bentuk profil baja ringan yang bervariasi seiring perkembangan dan terobosan teknologi manufaktur pabrik produsen. Pembentukan bentuk baja ringan adalah dengan proses penggilingan dingin, jadi profil dapat dibentuk dengan bentukan yang memiliki optimasi yang lebih. Maka perlu adanya tinjauan mengenai nilai kuat lentur dari modifikasi bentuk baja ringan tersebut. Penelitian diuji pada profil kanal $\mathrm{C}$ dengan dua bentuk variasi sayap dan badan profil yang bermutu G550 (AS1397). Pengujian menggunakan Finite Elemen Method dengan ANSYS Workbench dan menghasilkan parameter Total Deformation, Equivalent Stress dan Equivalent Elastic Strain. Hasil penelitian menunjukkan Profil C2 memiliki nominal kuat lentur terbesar yaitu $170258.8 \quad(\mathrm{~N} / \mathrm{mm} 2)$ dikarenakan memiliki inersia yang lebih besar dari $\mathrm{C} 1$ dan $\mathrm{C} 3$.

\section{METODOLOGI PENELITIAN}

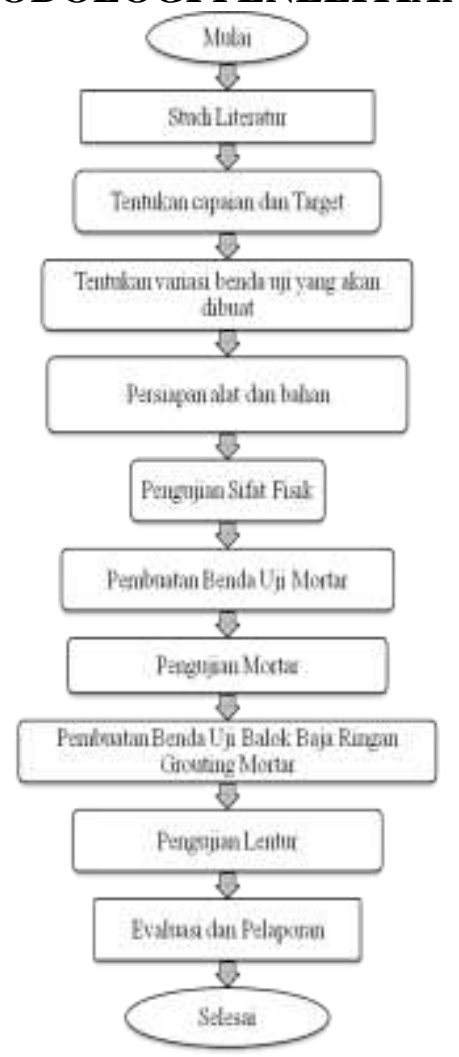

Gambar 1. Diagram Alir Penelitian
Semen yang digunakan adalah semen portlan tipe I. Agregat halus yang digunakan didapat dari daerah Tanjung Raja Kabupaten Ogan Ilir Sumatera Selatan. Adapun variasi benda uji yang dibuat berdasarkan variasi mortar yang digrouting kedalam baja ringan dapat dilihat pada Tabel 1 dan Tabel 2.

Tabel 1. Variasi Pengujian Mortar

\begin{tabular}{ccc}
\hline No. & Variasi Mortar & Umur (Hari) \\
\hline 1. & $1: 1$ & 28 \\
\hline 2. & $1: 2$ & 28 \\
\hline 3. & $1: 3$ & 28 \\
\hline 4. & $1: 4$ & 28 \\
\hline
\end{tabular}

Tabel 2. Variasi Pengujian Lentur Baja Ringan Grouting Mortar

\begin{tabular}{ccc}
\hline No. & Variasi Mortar & Umur (Hari) \\
\hline 1. & $1: 1$ & 28 \\
\hline 2. & $1: 2$ & 28 \\
\hline 3. & $1: 3$ & 28 \\
\hline 4. & $1: 4$ & 28 \\
\hline 5. & Tanpa Mortar & - \\
\hline
\end{tabular}

\section{HASIL DAN PEMBAHASAN}

4.1 Hasil Pengujian Fisik Bahan

Pada penelitian ini dilakukan pengujian sifat fisik bahan yang akan digunakan. Adapun maksud Semen yang digunakan adalah semen portland tipe I. Berdasarkan hasil pengujian konsistensi semen memenuhi syarat [6] dengan penurunan sebesar $11 \mathrm{~mm}$ dengan kandungan air sebanyak 24\%. Jumlah air tersebut telah memenuhi standar dimana jumlah air untuk mencapai konsistensi normal semen berkisar antara $22 \%-28 \%$. Pengujian waktu ikat semen membutuhkan waktu selama 104,5 menit dengan metode pengujian telah memenuhi syarat [6]. Pengujian berat jenis semen portland tipe I sebesar 3,09 $\mathrm{gr} / \mathrm{m} 3$. Nilai berat jenis semen tersebut telah memenuhi nilai standar . Adapun nilai standar untuk berat jenis semen yaitu sebesar 3,0 - 3,2 gr/m3.

Dari pengujian berat jenis bulk/density agregat halus didapat nilai rata-rata $2,15 \mathrm{gr} / \mathrm{m} 3$ dan berat jenis Saturated Surface Dry (SSD) nilai rata-rata $2,21 \mathrm{gr} / \mathrm{m} 3$ berdasarkan [7] nilai tersebut memenuhi standar nilai yang 
disyaratkan untuk berat jenis. Sedangkan pengujian analisis saringan mengikuti metode [8] hasil analisis saringan agregat halus termasuk dalam zona 3 seperti yang terlihat pada Gambar 2.

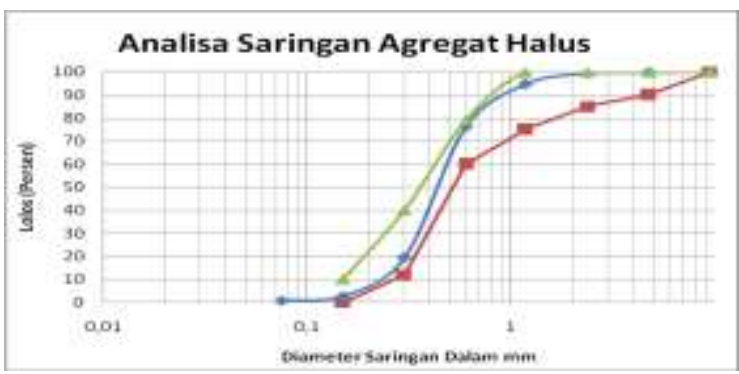

Gambar 2. Analisa Saringan Agregat Halus Zona 3

\subsection{Hasil Pengujian Kuat Tekan Mortar}

Setelah melakukan uji fisik sifat bahan maka langkah selanjutnya adalah membuat komposisi perhitungan bahan pembuat mortar dan membuat benda uji mortar. Benda uji mortar yang telah dibuat akan dilakukan perawatan dengan proses perendaman didalam air selama 28 hari lalu setelah itu benda uji mortar akan dilakukan uji tekan [9] seperti pada Gambar 3.

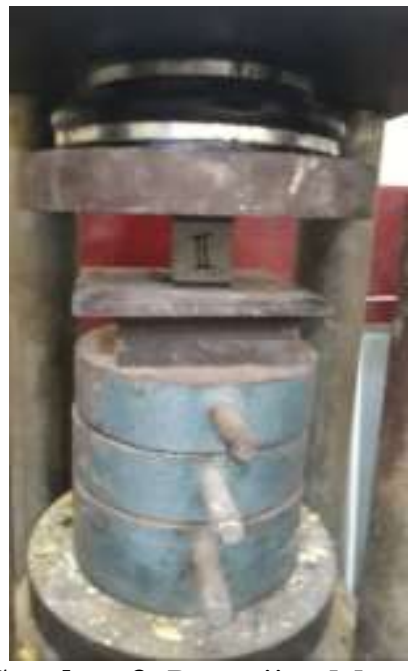

Gambar 3. Pengujian Mortar

Hasil pengujian mortar dapat dilihat pada Gambar 4. Dari hasil pengujian kuat tekan mortar maka didapatkan hasil bahwa semakin besar perbandingan penggunaan campuran pasir dan semakin sedikit penggunaan campuran semen dapat mengakibatkan kuat tekan mortar berkurang. Campuran semen memiliki fungsi sebagai bahan pengikat dalam adukan mortar sehingga semakin sedikit semen maka bahan pengikat semakin berkurang. Dalam proses pengerjaan pembuatan mortar didapat kesulitan pengerjaan dikarenakan semakin berkurangnya semen yang digunakan maka akan membuat sifat kelecakan mortar semakin berkurang.

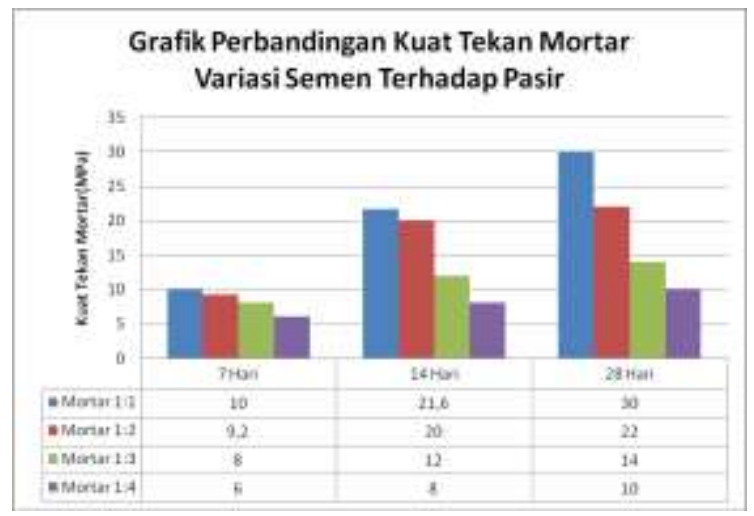

Gambar 4. Grafik Perbandingan Kuat Tekan Mortar Variasi Perbandingan Semen Terhadap Pasir

\subsection{Hasil Pengujian Uji Lentur Balok}

Setelah melakukan uji kuat tekan mortar maka langkah selanjutnya adalah membuat komposisi perhitungan bahan pengisi atau grouting mortar kedalam baja ringan dan menggrouting baja ringan dengan variasi campuran semen dengan perbandingan 1:1, 1:2, $1: 3$, dan 1:4. Balok baja ringan yang telah digrouting akan dilakukan uji kuat lentur setelah berumur 28 hari seperti yang terlihat pada Gambar 5.

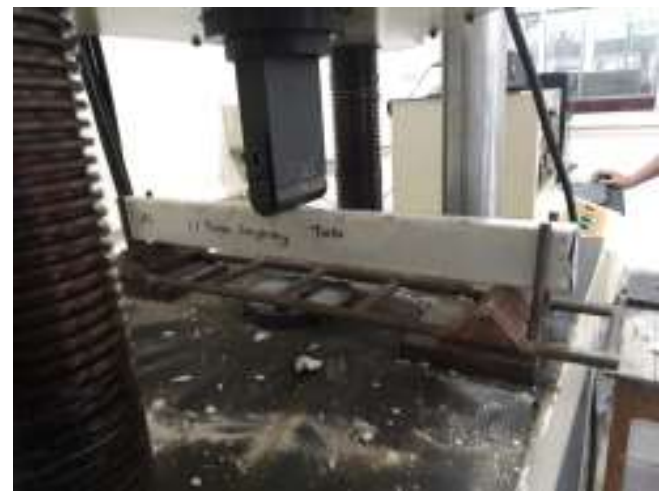

Gambar 5. Pengujian Lentur Balok Baja Ringan Grouting Mortar

Dapat dilihat pada Gambar 5 merupakan proses pengujian lentur balok baja ringan yang digrouting mortar dengan beberapa variasi. Langkah ini dilakukan setelah membuat benda uji mortar kemudian setelah umur balok baja 
ringan 28 hari maka dilakukan pengujian lentur dengan satu beban titik dan didapatkan hasil yang dapat dilihat pda Gambar 6.

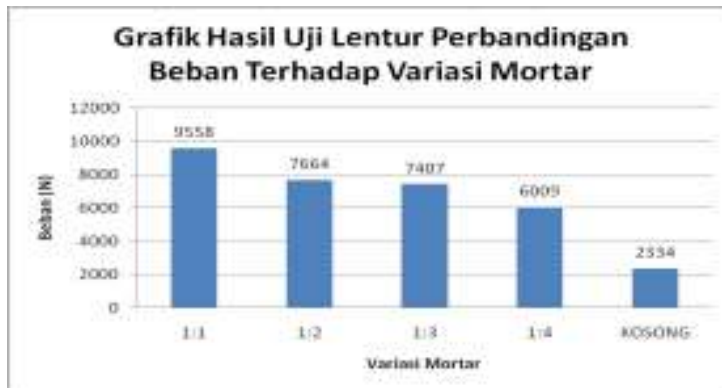

Gambar 6. Grafik Hasil Uji Lentur Perbandingan Beban Terhadap Variasi Mortar

Pada Gambar 6 dapat dilihat bahwa semakin besar perbandingan pasir terhadap semen yang digunakan maka semakin kecil beban yang mampu ditahan oleh balok baja ringan. Sedangkan untuk balok baja ringan yang tidak digrouting mortar memiliki tahanan beban yang paling kecil. Hal ini disebabkan oleh sifat baja ringan yang lemah terhadap tekan. Oleh karena itu diperlukan bahan pengisi baja ringan dan dari hasil pengujian campuran mortar 1:1 memiliki nilai tahanan beban yang paling besar yaitu sebesar 9558 Newton dan tahanan beban paling kecil dimiliki oleh balok baja ringan tanpa bahan pengisi mortar sebesar 2334 Newton.

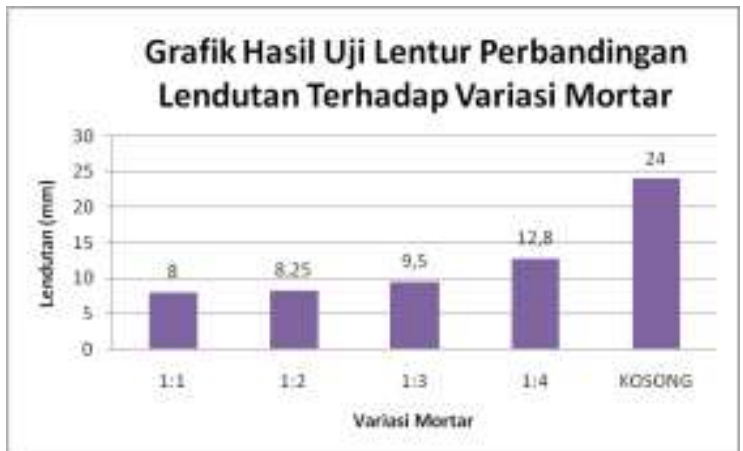

Gambar 7. Grafik Hasil Uji Lentur
Perbandingan
Terhadap Variasi Mortar

Pada Gambar 7 dapat dilihat bahwa semakin besar perbandingan pasir terhadap semen yang digunakan maka semakin besar lendutan yang ditahan oleh balok baja ringan. Sedangkan untuk balok baja ringan yang tidak digrouting mortar memiliki lendutan yang paling besar. Dari hasil pengujian campuran mortar 1:1 memiliki nilai lendutan beban yang paling kecil yaitu sebesar $8 \mathrm{~mm}$ dan terbesar lendutan balok baja ringan tanpa mortar yaitu $24 \mathrm{~mm}$.

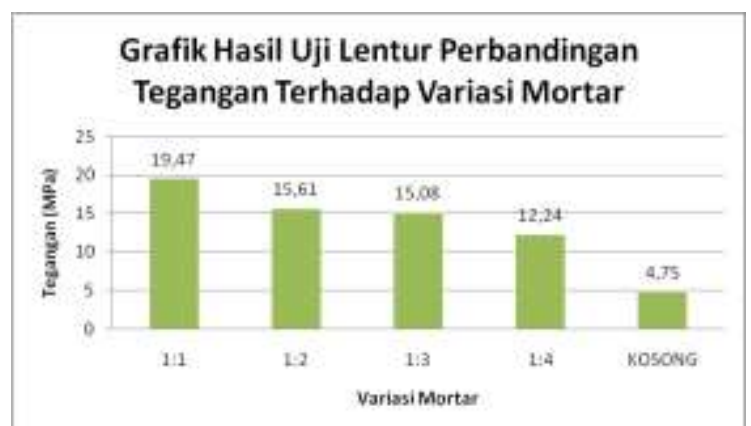
Gambar 8. Grafik Hasil Uji Lentur Perbandingan Lendutan Terhadap Variasi Mortar

Pada Gambar 8 dapat dilihat bahwa semakin besar perbandingan pasir terhadap semen yang digunakan maka semakin kecil tegangan balok baja ringan. Sedangkan untuk balok baja ringan yang tidak digrouting mortar memiliki tegangan yang paling kecil. Dari hasil pengujian campuran mortar 1:1 memiliki nilai tegangan yang paling besar yaitu sebesar 19,47 $\mathrm{MPa}$ dan terkecil balok baja ringan tanpa mortar yaitu 4,75 MPa.

\section{KESIMPULAN}

Kesimpulan yang dapat diambil setelah melaksanakan penelitian ini adalah sebagai berikut :

(i) Semakin sedikitnya bahan pengikat atau semen yang digunakan maka mengakibatkan kuat tekan mortar yang mengalami penurunan;

(ii) Dari hasil pengujian untuk tahanan beban yang paling besar dimiliki oleh variasi balok baja ringan yang digrouting mortar 1:1 dan tahanan beban paling kecil dimiliki oleh balok baja ringan tanpa bahan pengisi atau grouting mortar;

(iii) Dari hasil pengujian untuk lendutan yang paling kecil dimiliki oleh variasi balok baja ringan yang digrouting mortar 1:1 dan lendutan paling besar dimiliki oleh balok baja ringan tanpa bahan pengisi atau grouting mortar; dan

(iv) Dari hasil pengujian untuk tegangan yang paling besar dimiliki oleh variasi balok baja ringan yang digrouting mortar 1:1 dan tegangan paling kecil dimiliki oleh balok 
baja ringan tanpa bahan pengisi atau grouting mortar

\section{DAFTAR PUSTAKA}

[1] Agus Setiawan, Perencanaan Struktur Baja Dengan Metode LRFD, Jakarta, 2008:18

[2] Felisa Octaviani, dkk., Pengujian Kuat Tekan Mortar dan Beton Ringan Dengan MenggunakanAgregat Ringan Batu Apung dan Abu Sekam Padi Sebagai Substitusi Parsial Semen, Vol. 4, Jurnal Sipil Statik, 2016:2337-6732.

[3] Andi M.K., dkk., Investigasi Eksperimental Perilaku Profil Baja Ringan Berpenampang Persegi Akibat Interaksi Beban Tekan Memusat dan Momen Lentur, Vol 28.1.2013 Majalah Metalurgi, 2013 : 33-48

[4] Kezia Ruus, dkk., Pengaruh Bentuk Badan Profil Baja Ringan Terhadap Kuat Tekan, Vol.5, Jurnal Sipil Statik, 2017: 23376732

[5] Gabriela S.S., dkk., Analisis Kuat Lentur Baja
Ringan Dengan Variasi Bentuk Sayap dan Badan Penampang, Vol. 7, Jurnal Sipil Statik, 2019: 1245-1250.

[6] Badan Standarisasi Nasional, Semen Portland, SNI 15-2049-2004, Indonesia

[7] Badan Standarisasi Nasional, Semen Portland, SNI 15-2049-2004, Indonesia

[8] Badan Standarisasi Nasional, Metode Pengujian Tentang Analisis Saringan Agregat Halus dan Kasar, SNI 03-1968-1990, Indonesia

[9] Badan Standarisasi Nasional, Metode Pengujian Kekuatan Tekan Mortar Semen Portland Untuk Pekerjaan Sipil, SNI 03-6825-2002, Indonesia 